\title{
High variability of climate and surface mass balance induced by Antarctic ice rises
}

\author{
Jan T.M. LENAERTS, ${ }^{1}$ Joel BROWN ${ }^{2}$ Michiel R. VAN DEN BROEKE, ${ }^{1}$ \\ Kenichi MATSUOKA, ${ }^{2}$ Reinhard DREWS, ${ }^{3}$ Denis CALLENS, ${ }^{3}$ Morgane PHILIPPE, ${ }^{3}$ \\ Irina V. GORODETSKAYA, ${ }^{4}$ Erik VAN MEIJGAARD, ${ }^{5}$ Carleen H. REIJMER, ${ }^{1}$ \\ Frank PATTYN, ${ }^{3}$ Nicole P.M. VAN LIPZIG ${ }^{4}$ \\ ${ }^{1}$ Institute for Marine and Atmospheric Research, Utrecht University, Utrecht, The Netherlands \\ E-mail: j.lenaerts@uu.nl \\ ${ }^{2}$ Norwegian Polar Institute, Tromsø, Norway \\ ${ }^{3}$ Laboratoire de Glaciologie, Université Libre de Bruxelles, Brussels, Belgium \\ ${ }^{4}$ Department of Earth and Environmental Sciences, KU Leuven - University of Leuven, Leuven, Belgium \\ ${ }^{5}$ Royal Netherlands Meteorological Institute, De Bilt, The Netherlands
}

\begin{abstract}
Ice rises play key roles in buttressing the neighbouring ice shelves and potentially provide palaeoclimate proxies from ice cores drilled near their divides. Little is known, however, about their influence on local climate and surface mass balance (SMB). Here we combine 12 years (2001-12) of regional atmospheric climate model (RACMO2) output at high horizontal resolution $(5.5 \mathrm{~km})$ with recent observations from weather stations, ground-penetrating radar and firn cores in coastal Dronning Maud Land, East Antarctica, to describe climate and SMB variations around ice rises. We demonstrate strong spatial variability of climate and SMB in the vicinity of ice rises, in contrast to flat ice shelves, where they are relatively homogeneous. Despite their higher elevation, ice rises are characterized by higher winter temperatures compared with the flat ice shelf. Ice rises strongly influence SMB patterns, mainly through orographic uplift of moist air on the upwind slopes. Besides precipitation, drifting snow contributes significantly to the ice-rise SMB. The findings reported here may aid in selecting a representative location for ice coring on ice rises, and allow better constraint of local ice-rise as well as regional ice-shelf mass balance.
\end{abstract}

KEYWORDS: accumulation, Antarctic glaciology, ice rise, surface mass budget, wind-blown snow

\section{INTRODUCTION}

The Antarctic ice sheet is the largest body of ice on Earth, with an area of $\sim 14 \times 10^{6} \mathrm{~km}^{2}$. Most of its area $(>80 \%)$ is grounded, but along $74 \%$ of its margins large floating ice shelves buttress the ice sheet (Bindschadler and others, 2011). Ice shelves are mostly flat, but local 'pinning points' attach them to the ocean bed below (Hughes, 1977; Jezek and Bentley, 1983; Alley and others, 1989; Horgan and Anandakrishnan, 2006; Fricker and others, 2009; Jenkins and others, 2010). If these features are surrounded entirely by the ice shelf, they are called ice rises; otherwise they are referred to as ice domes or promontories. In this paper we generalize all these features and refer to them as ice rises. These have a higher elevation $(50-500 \mathrm{~m}$ ) than the surrounding floating ice and are associated with locally very low ice velocities. Since the ice below some of these features can be thousands of years old (Bindschadler and others, 1990; Martín and others, 2006, 2014; Drews and others, 2013), ice cores can provide long-term estimates of past climate and local surface mass-balance $(\mathrm{SMB})$ variations. The SMB (mmw.e. $\left.\mathrm{a}^{-1}\right)$ is defined as the difference between annual surface mass gain (precipitation, PR) and surface mass loss (surface runoff, RU, surface sublimation, $\mathrm{SU}_{\mathrm{s}}$, drifting snow sublimation, $\mathrm{SU}_{\mathrm{ds}}$ and drifting snow erosion, $\mathrm{ER}_{\mathrm{ds}}$ ):

$$
\mathrm{SMB}=\int \mathrm{PR}-\mathrm{RU}-\mathrm{SU}_{\mathrm{s}}-\mathrm{SU}_{\mathrm{ds}}-\mathrm{ER}_{\mathrm{ds}} \mathrm{d} t .
$$

Note that $E R_{\mathrm{ds}}$ can be negative (drifting snow deposition) and thereby contribute to surface mass gain. Since ice rises are grounded features with topographic expression above the surrounding ice shelf, they act as local barriers to the prevalent atmospheric flow. In a similar way to grounded ice barriers elsewhere, such as southeastern Greenland (Miège and others, 2013), the West Antarctic topographic ridge (Nicolas and Bromwich, 2011) and the Antarctic Peninsula (Van Lipzig and others, 2004; Van den Broeke and others, 2006), they could enhance orographic precipitation on the upwind side of the ridge, with a precipitation shadow on the downwind side (Fernandoy and others, 2010). In addition, they might disturb the local wind field, which promotes the contribution of drifting snow processes to the local SMB (Nereson and Waddington, 2002; King and others, 2004). In situ measurements on and around ice rises are extremely sparse and do not provide the spatial coverage needed to analyse the effect of ice-rise topography on SMB. Alternatively, remote sensing or regional climate modelling provide a gridded SMB field. However, commonly used Antarctic SMB maps (Arthern and others, 2006; Van de Berg and others, 2006; Lenaerts and others, 2012a) have a horizontal resolution $(\sim 25-50 \mathrm{~km})$ that is too low to properly resolve most ice rises (typical radius $<20 \mathrm{~km}$ ). Iceshelf SMB is therefore usually assumed homogeneous in ice-sheet models that study the dynamic behaviour of the Antarctic ice sheet and shelves (Winkelmann and others, 2012; Wright and others, 2013; Kleiner and Humbert, 2014) 


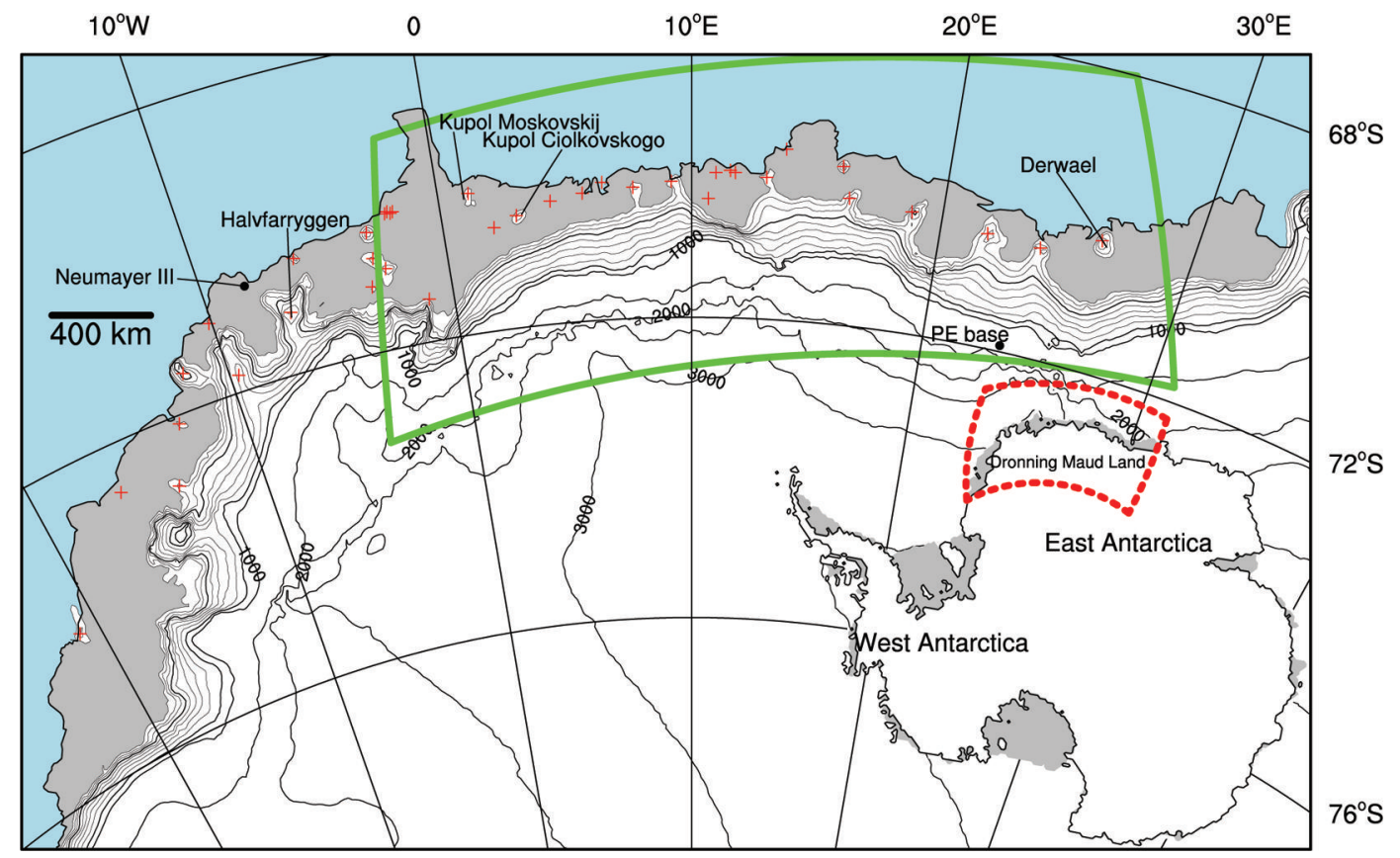

Fig. 1. RACMO2 topography inside the model domain (Bamber and others, 2009), with $100 \mathrm{~m}$ vertical spacing from 0 to $1000 \mathrm{~m}$ a.s.l. and $500 \mathrm{~m}$ spacing from 1000 to $4000 \mathrm{~m}$ a.s.I. Blue represents the ocean, grey the ice shelf and white the grounded ice. The red crosses indicate locations of ice rises. The green box shows the extent of the maps presented in Figures 3, 5a and 7. The red box in the inset map shows the location of the domain on Antarctica. Locations discussed in the paper are indicated on the map.

and the role of ice rises therein (Matsuoka and others, 2012; Pattyn and others, 2012).

This study is the first attempt to focus on climate and SMB variability around ice rises. We present combined results from high-resolution regional climate modelling and recently obtained in situ meteorological data and SMB measurements, and describe the near-surface climate and SMB on and around ice rises in Dronning Maud Land (DML), East Antarctica, where many small ice rises are located. The following section describes the model set-up and presents the observational data. The next section describes the results and the final section presents the implications of this study and conclusions.

\section{METHODS}

\section{Regional atmospheric climate model}

We use the output of the high-resolution $(\sim 5.5 \mathrm{~km}$ horizontal gridding) regional atmospheric climate model RACMO2, version 2.3 (Lenaerts and others, 2014; Van Wessem and others, 2014), with its spatial domain focused on DML $\left(\sim 25^{\circ} \mathrm{W}\right.$ to $\left.\sim 35^{\circ} \mathrm{E}\right)$ (Fig. 1$)$. RACMO2 has been used before to map Antarctic SMB at a lower horizontal resolution ( $\sim 27 \mathrm{~km}$; Lenaerts and others, 2012a), but that resolution is insufficient to properly resolve the topography of an average-sized ice rise.

RACMO2 is forced at its lateral boundaries by atmospheric profiles of the ERA-Interim reanalysis from the European Centre for Medium-range Weather Forecasts (ECMWF 2001-12; Dee and Uppala, 2009), and is free to evolve in its inner spatial domain. The relaxation zone, where the ERA-Interim fields are downscaled to RACMO2 resolution, is sufficiently wide ( $32 \mathrm{RACMO} 2$ gridpoints, i.e. $\sim 180 \mathrm{~km}$ ) and located over the ocean where possible. Seasurface temperature and sea-ice extent in RACMO2 are also prescribed by the ERA-Interim analysis. The snow model that is interactively coupled with RACMO2 includes physical descriptions and temporal evolution of snowmelting, percolation and runoff (Ettema and others, 2010), snow albedo (Kuipers Munneke and others, 2011) and drifting snow (Lenaerts and others, 2012b). The snowpack is initialized with data from a previous RACMO2 simulation (Lenaerts and others, 2012a).

\section{Elevation model}

In this study, we use the digital elevation model (DEM) provided by Bamber and others (2009), which has been compiled from satellite-based laser and radar altimetry from the Ice, Cloud and land Elevation Satellite (ICESat) and European Remote-sensing Satellite (ERS), respectively. It covers the entire Antarctic continent and is gridded to $1 \mathrm{~km}$ postings. The ice rises in our sector of interest appear clearly in the DEM, even after regridding this DEM to the RACMO2 horizontal resolution $(5.5 \mathrm{~km}$; Fig. 1$)$. However, ice rises have relatively steep surface slopes, which introduces errors into the DEM, since the altimeter reflections do not originate from the sub-satellite points. This may result in locally large elevation errors (e.g. Drews and others, 2009; Wesche and others, 2009). In the future, such problems will be overcome, for example, by using the interferometric capabilities of CryoSat-II (Helm and others, 2014). In this study, however, we decide to use the DEM of Bamber and others (2009), because it provides a spatially continuous and consistent dataset. We keep in mind that errors in the applied elevation model will propagate to simulated absolute SMB values; however, we expect that the simulated SMB gradients will not alter dramatically with an improved DEM.

\section{Meteorological data}

To evaluate the temperature, precipitation and SMB simulated by RACMO2, we use data from three weather stations 


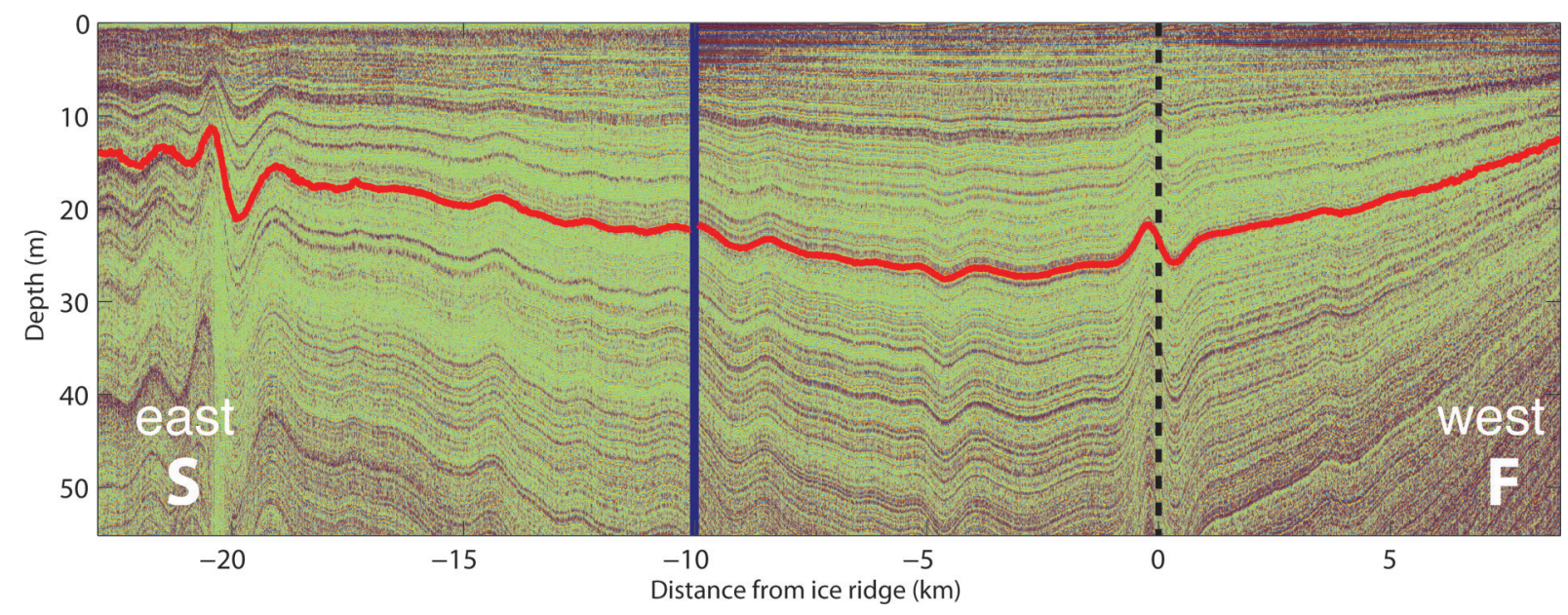

Fig. 2. GPR profile along Derwael Ice Rise. Note that the transect runs from the upwind slope (S) to the downwind slope (F), i.e. from east to west. The red curve denotes the selected reflector for the SMB estimation. The dashed black line is the position of the ridge and the firn core (Hubbard and others, 2013). The blue line denotes the separation between the data obtained in 2012 and in 2013.

(Fig. 1). The permanently manned station, Neumayer III, is located on the flat Ekström Ice Shelf, $\sim 20 \mathrm{~km}$ from the iceshelf edge, and has provided quality-controlled, detailed meteorological observations since 1983. We use daily averaged data covering the period January 2011-December 2011 (König-Langlo, 2011). We also use daily averaged data for 2011 from an automatic weather station (AWS11; Van den Broeke and others, 2004) installed on the ridge of Halvfarryggen, an ice promontory located $\sim 120 \mathrm{~km}$ southeast of Neumayer III ( 700 m a.s.l.; Drews and others, 2013; Van Wessem and others, 2014). Finally, we use measurements of snowfall and snow height (2009-12) and snowfall rate (2011-12) available from the Princess Elisabeth base (PE base; Fig. 1). PE base is located on Utsteinen ridge (1390 ma.s.I.; $72^{\circ} \mathrm{S}, 23^{\circ} \mathrm{E}$ ) just north of the Sør Rondane mountains in the escarpment area of eastern DML, $\sim 200 \mathrm{~km}$ southwest of the ice-shelf edge. The snow height was measured by a sonic height ranger installed as part of AWS16, located in a valley $300 \mathrm{~m}$ east of PE base; annual SMB was inferred using an annual mean snow density measured on site (Gorodetskaya and others, 2013). Snowfall rate is derived from a micro rain radar 2 (MRR) vertically profiling $24 \mathrm{GHz}$ radar installed at PE (Gorodetskaya and others, 2014a), hereafter referred to as snow radar. Here we use daily total snowfall rates, $S$, estimated based on the nearsurface radar reflectivity, Ze. Uncertainty in snowfall rate estimates depending on snow-particle microphysical properties is considered by applying a range of $Z e / S$ relationships for dry snow (Matrosov, 2007). Although PE base is not located on or near an ice rise, it retrieves the only direct measurements of snowfall in DML.

\section{Snow stakes and firn cores}

Along with the model evaluation using meteorological data, we compare the RACMO2 SMB with local SMB estimates derived from a combination of snow-stake and firn-core measurements. In January 2012, we placed a network of 73 aluminium stakes on Kupol Ciolkovskogo and 79 stakes on Kupol Moskovskij (Fig. 1) as part of a GPS occupation campaign. We placed $3 \mathrm{~m}$ long aluminium stakes $\sim 1 \mathrm{~m}$ into the snow surface, measured the initial height of each stake from the snow surface, and reoccupied the measurement 1 year later. To ensure that the aluminium stakes were well anchored, they were manually driven into the snow to a hard layer at $\sim 1 \mathrm{~m}$ depth. We assume that the magnitude of firn compaction is much smaller than the measured stake height difference related to SMB. We believe that this is a valid assumption in this case, since we are solely interested in the SMB pattern over the ice rises, rather than the absolute value of the single-year $\mathrm{SMB}$ values.

In order to determine the local SMB from the stake snow heights, we collected $3 \mathrm{~m}$ firn cores at six locations on Kupol Ciolkovskogo and 14 locations on Kupol Moskovskij in January 2013. We measured the length, diameter and mass of each core section. The cumulative length of the measured core sections does not correspond to the relative stake height differences at the locations; to estimate the density of the surface layer, we calculate the weighted mean density of multiple core sections to the depth of the accumulated snow. To estimate the error due to horizontal variability in nearsurface density (the cores and the stakes are $<5 \mathrm{~m}$ apart), we drilled two separate cores close to one another. The resulting $\mathrm{SMB}$ error is assumed equal to three times the observed SMB difference between the cores, i.e. $15 \mathrm{~mm}$ w.e. $\mathrm{a}^{-1}$.

\section{Ground-penetrating radar}

Ground-penetrating radar (GPR) is a standard method to spatially extrapolate accumulation measurements from firn cores (e.g. Spikes and others, 2004; Eisen and others, 2008). The underlying principle assumes that shallow, laterally continuous internal-reflection horizons in the radar data are isochrones that are not deformed significantly by ice dynamics (shallow-layer approximation; Waddington and others, 2007). For data regarding Halvfarryggen and Derwael Ice Rise, only one firn core was available, which necessitates the additional assumption that the depth/density profile does not change laterally.

The radar profile on Derwael Ice Rise presented in Figure 2 was collected in 2012 and spatially extended by $\sim 10 \mathrm{~km}$ towards the southeast in 2013. It was acquired using a commercial $400 \mathrm{MHz}$ antenna. For the travel-time to depth conversion, we use a velocity/density model based on the mixing formula given by Looyenga (1965). The density/ depth scale stems from a combination of discrete firn-core samples (Hubbard and others, 2013) and a semi-empirical firn-compaction model (Arthern and others, 2010). For the 

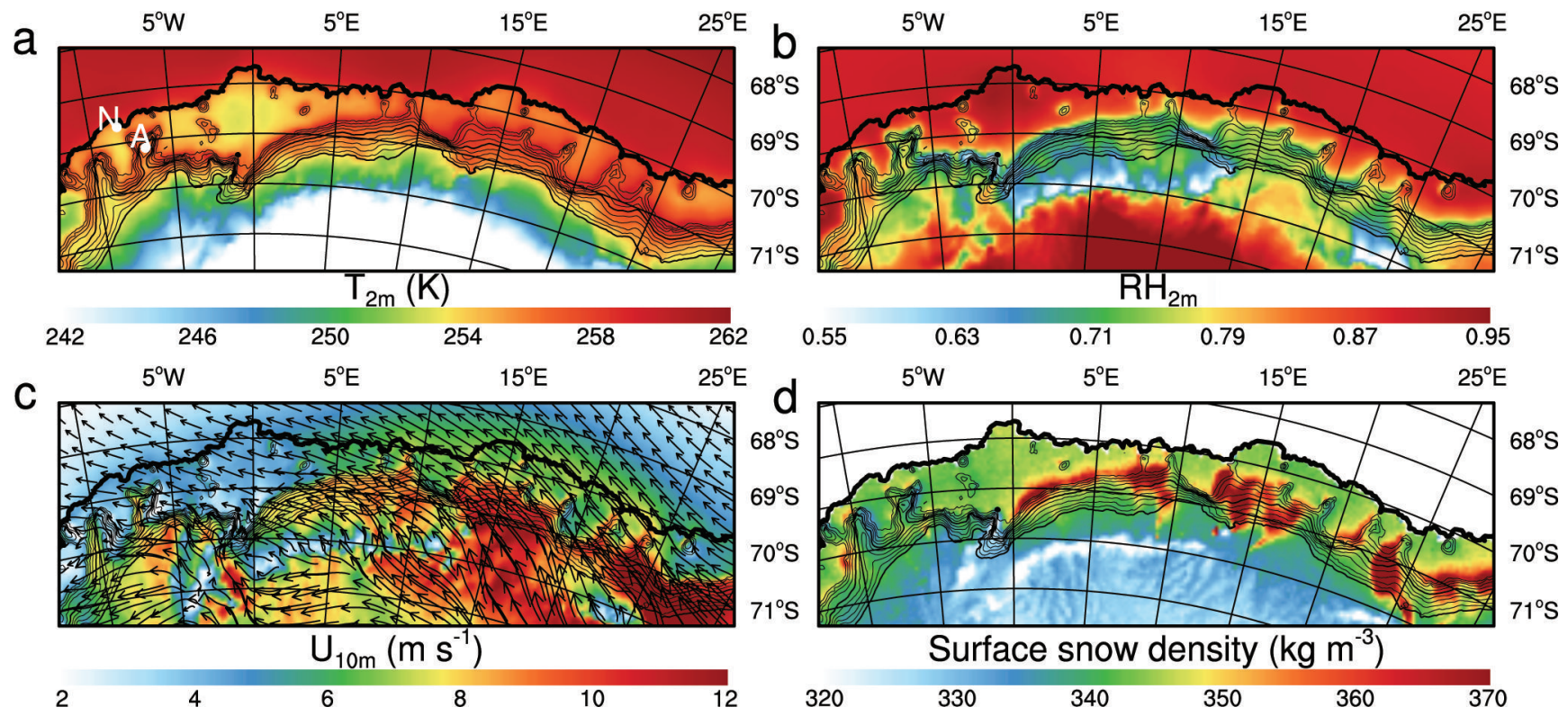

Fig. 3. Simulated annual mean (2001-12) near-surface climate in the region $10^{\circ} \mathrm{W}-10^{\circ} \mathrm{E}$. (a) $2 \mathrm{~m}$ temperature (K). (b) $2 \mathrm{~m}$ relative humidity

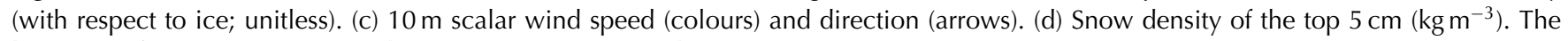
locations of Neumayer III (N) and AWS11 (A) (Fig. 4) are shown in (a).

latter, we assume steady state, with a surface subsidence rate equal to the $\mathrm{SMB}$ divided by the measured surface density, $400 \mathrm{~kg} \mathrm{~m}^{-3}$, and a surface temperature of $-15^{\circ} \mathrm{C}$. Both values are derived from the firn core drilled on the Derwael Ice Rise divide (Hubbard and others, 2013). The model is vertically integrated until ice density $\left(917 \mathrm{~kg} \mathrm{~m}^{-3}\right)$ is reached. We minimize the difference to the core samples by adjusting the activation energy for grain growth to $E_{\mathrm{g}}=41 \mathrm{~kJ} \mathrm{~mol}^{-1}$, which closely matches the values given by Cuffey and Paterson (2010).

After the travel-time to depth conversion, a single internal-reflection horizon was dated using the annual variability in stable isotopes $\left(\delta^{18} \mathrm{O}\right)$ measured in the firn core. Near the core site, the internal-reflection horizon is at $22 \mathrm{~m}$ depth and the corresponding age is 21 years before 2012. We pick the same isochrone in both datasets, using the characteristic pattern of internal-reflector packages, which is consistent in both datasets. Therefore the radarderived SMB is a 21 year average for data collected in 2012 and a 22 year average for data collected in 2013. The relative depth of the reflection horizon varies on either side of the divide, which results in the SMB gradient depicted in Figure 2. However, the absolute values derived here are associated with a number of uncertainties: the error of the tentative age/depth scale is \pm 1 year; the root-mean-square error between the density/depth model and the firn-core data is $\pm 18 \mathrm{~kg} \mathrm{~m}^{-3}$, which results in an additional uncertainty of $0.5 \mathrm{~m}$ in the conversion from travel time to depth. At the core site, the combined effect of the errors of age/depth scale and of the travel-time to depth conversion on the $\mathrm{SMB}$ is $\sim 8 \%$ (i.e. $\sim 40 \mathrm{~mm}$ w.e. $\mathrm{a}^{-1}$ ). We assume this error to be constant along the profile, since the age/depth estimate, which is vertically constant, involves the largest uncertainty. As the observed SMB gradient across Derwael Ice Rise greatly exceeds the associated error, we are confident that the pattern observed is realistic. Additional uncertainties, such as discontinuities between the 2012 and 2013 data, as well as the spatial separation between the radar profile and the core site $(\sim 400 \mathrm{~m}$ at the closest approach), are constant along the profile, which enhances robustness in the observed spatial gradient.

\section{RESULTS AND DISCUSSION \\ Temporal variability}

DML is a region characterized by a strong interannual variability of SMB (Reijmer and Van den Broeke, 2001; Schlosser and others, 2010; Lenaerts and others, 2013). Therefore, it is questionable whether 2001-12 is a representative period for the longer-term mean climate. However, when analysing the Antarctic-wide, long-term (1979-2013) RACMO2 simulation $(27 \mathrm{~km}$ horizontal resolution; Van Wessem and others, 2014), the 2001-12 DML ice-shelf SMB (331 mm w.e. $\mathrm{a}^{-1}$ ) does not differ significantly from the 1979-2013 value $\left(324 \pm 48 \mathrm{~mm}\right.$ w.e. $\mathrm{a}^{-1}$ (mean \pm standard deviation)). Hence, it is justified to present 2001-12 mean RACMO2 results as a reliable proxy for the long-term, multidecadal DML climate.

\section{Near-surface climate}

Figure 3 presents the simulated mean near-surface climate. Over the ice shelves, near-surface temperature is low $(\sim 254 \mathrm{~K})$ and relative humidity high $(\sim 90 \%)$. They remain nearly uniform over the ice shelves, whereas higher temperatures and lower relative humidities are found over the lower escarpment region connecting the Antarctic plateau with the ice shelves, but also on the ice rises.

This is further illustrated by comparing daily mean temperature at two neighbouring weather stations (Fig. 4), Neumayer III and AWS11, the latter located $\sim 650 \mathrm{~m}$ higher than Neumayer III. The difference in elevation results in higher temperatures at Neumayer III in summer (3-4 K), when the surface-based temperature inversion is rather weak. In winter, however, we see prolonged periods with comparable or even higher near-surface temperatures at AWS11. This mainly occurs during periods when the temperature at 


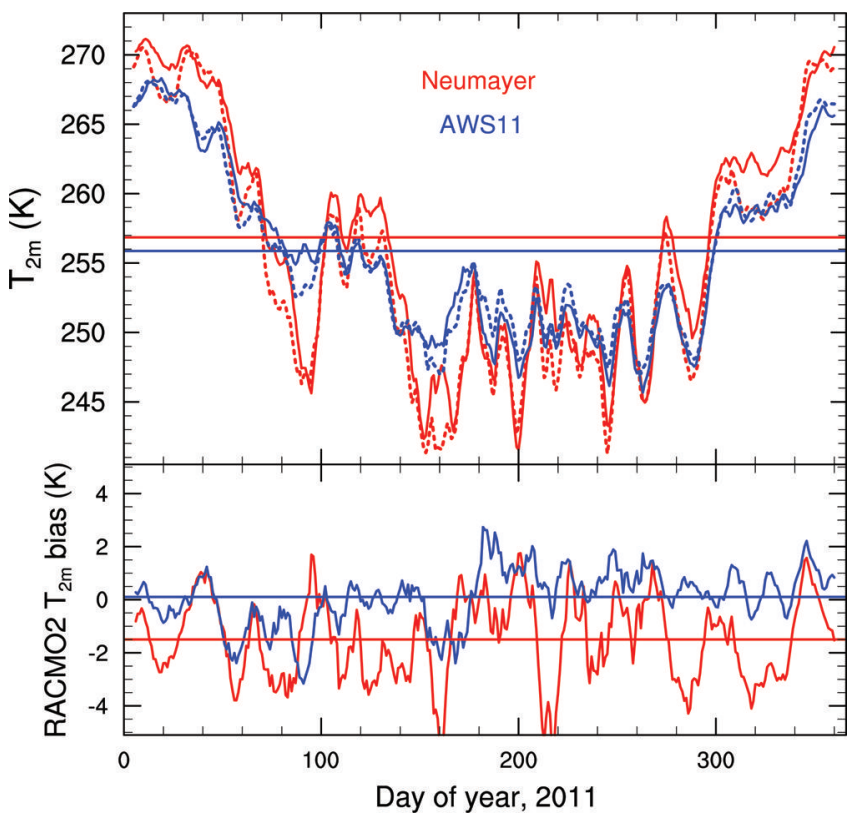

Fig. 4. Ten-day running mean, $2 \mathrm{~m}$ temperature observed (solid) and modelled (dotted) at Neumayer III (red) and AWS11 (blue). Horizontal bars show the annual mean observed values. The bottom panel shows deviation of the modelled values from the observed values (RACMO2 - observations). Horizontal bars show the annual mean deviations at these two sites. (Fig. 3 shows the locations of these sites.)

Neumayer III is very low $(<245 \mathrm{~K})$, i.e. when a strong temperature inversion sets up above the ice-shelf surface, and the temperatures at AWS11 can be 5-10 K higher than at Neumayer III. In 2011, the annual mean temperature was observed to be $256.8 \mathrm{~K}$ at Neumayer III and $255.9 \mathrm{~K}$ at AWS11, i.e. only a small $(0.9 \mathrm{~K})$ temperature difference between an ice shelf and an ice-rise weather station, despite a significant elevation difference $(\sim 650 \mathrm{~m})$. RACMO2 simulates this behaviour relatively well, but, despite a correct representation of the elevation difference between Neumayer III and AWS11, it overestimates the effect: the annual mean temperature at Neumayer III is underestimated by $1.4 \mathrm{~K}$ $(255.4 \mathrm{~K})$, with frequent large underestimations in winter (Fig. 4), but RACMO2 agrees with the observed AWS11 temperature within $0.1 \mathrm{~K}(256.0 \mathrm{~K})$.

We argue that higher temperatures found over ice rises during cold periods are explained by two processes. Firstly, the ice rises are exposed to warmer surrounding air, because of the presence of a semi-permanent surface-based temperature inversion over the ice shelves (Connolley, 1996). Secondly, enhanced vertical mixing in the atmospheric surface layer in winter enhances the downward entrainment of warmer and drier air and partly breaks down the strong stably stratified atmosphere near the surface, which is supported by higher horizontal wind speeds over the ice rises (Fig. 3c), enhancing downward sensible heat flux. This implies that enhanced entrainment, through mechanical turbulence and exposure to warmer ambient air when a strong inversion forms over the surrounding ice shelf, is able to significantly raise near-surface temperatures of ice rises in winter.

\section{Surface mass balance}

Simulated mean (2001-12) SMB from RACMO2 in DML is displayed in Figure $5 \mathrm{a}$. Simulated SMB on the ice shelves surrounding the ice rises is relatively homogeneously
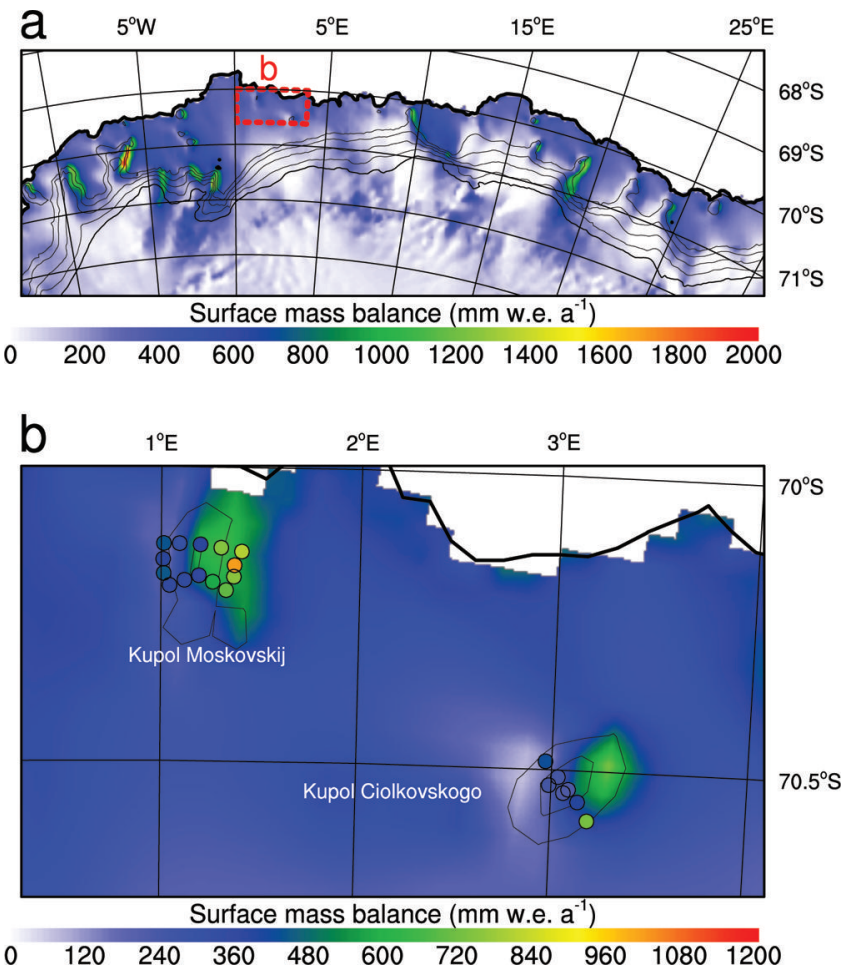

Fig. 5. RACMO2 mean (2001-12) annual SMB in (a) entire coastal DML; zoomed in (b) on Kupol Ciolkovskogo and Kupol Moskovskij $\left(0-4^{\circ} \mathrm{E}\right)$. The red box in (a) displays the location of (b). SMB values estimated using firn-core derived densities and stake heights are shown with circles. Contours show the surface topography (Bamber and others, 2009) with a resolution of $200 \mathrm{~m}$ in (a) and $100 \mathrm{~m}$ in (b).

distributed (200-400 mm w.e. $\mathrm{a}^{-1}$ ), but strong spatial SMB variations are found in the vicinity of all ice rises. Annual mean SMB values $>1000 \mathrm{~mm}$ w.e. $\mathrm{a}^{-1}$ are modelled on the northeastern (upwind) side of most topographic features, and a clear SMB minimum on the southwestern (downwind) sides. SMB of $>2000 \mathrm{~mm}$ w.e. $\mathrm{a}^{-1}$ are simulated on some upwind slopes in western DML (e.g. east of Halvfarryggen).

The 2012 DML ice shelves SMB in RACMO2 is insignificantly $(<5 \%)$ different from the 2001-12 mean (Van Wessem and others, 2014), which allows evaluation of RACMO2 SMB in more detail using single-year (2012) measurements around Kupol Ciolkovskogo and Kupol Moskovskij, located $\sim 1-3^{\circ}$ E (Fig. 1). On Kupol Ciolkovskogo, our measurements reveal that $2012 \mathrm{SMB}$ ranges between $225 \pm 15$ and $734 \pm 15 \mathrm{~mm}$ w.e. $\mathrm{a}^{-1}$ from the summit to the lowestelevation site on the upwind side of the ice rise. On the downwind side of the ice rise, the observed SMB ranges from $225 \pm 15$ to $428 \pm 15$ mm w.e. $\mathrm{a}^{-1}$. On Kupol Moskovskij, our 14 SMB measurements show that the single-year SMB ranges between $302 \pm 15 \mathrm{~mm}$ w.e. $\mathrm{a}^{-1}$ at the summit and $986 \pm 15 \mathrm{~mm}$ w.e. $\mathrm{a}^{-1}$ at the lowest-elevation sites on the upwind side of the ice rise. Together, these measurements constitute a spatially consistent single-year SMB pattern over ice rises, with highest SMB occurring at the low elevation on the upwind side of the ice rises.

Figure 5b compares these local SMB measurements with the mean $\mathrm{SMB}$ from RACMO2. We find RACMO2 SMB values of 1000 and $700 \mathrm{~mm}$ w.e. $\mathrm{a}^{-1}$ on the northeastern side of Kupol Ciolkovskogo and Kupol Moskovskij, respectively, whereas a significant SMB minimum is found west of the ice rises, mainly in the case of Kupol Ciolkovskogo 

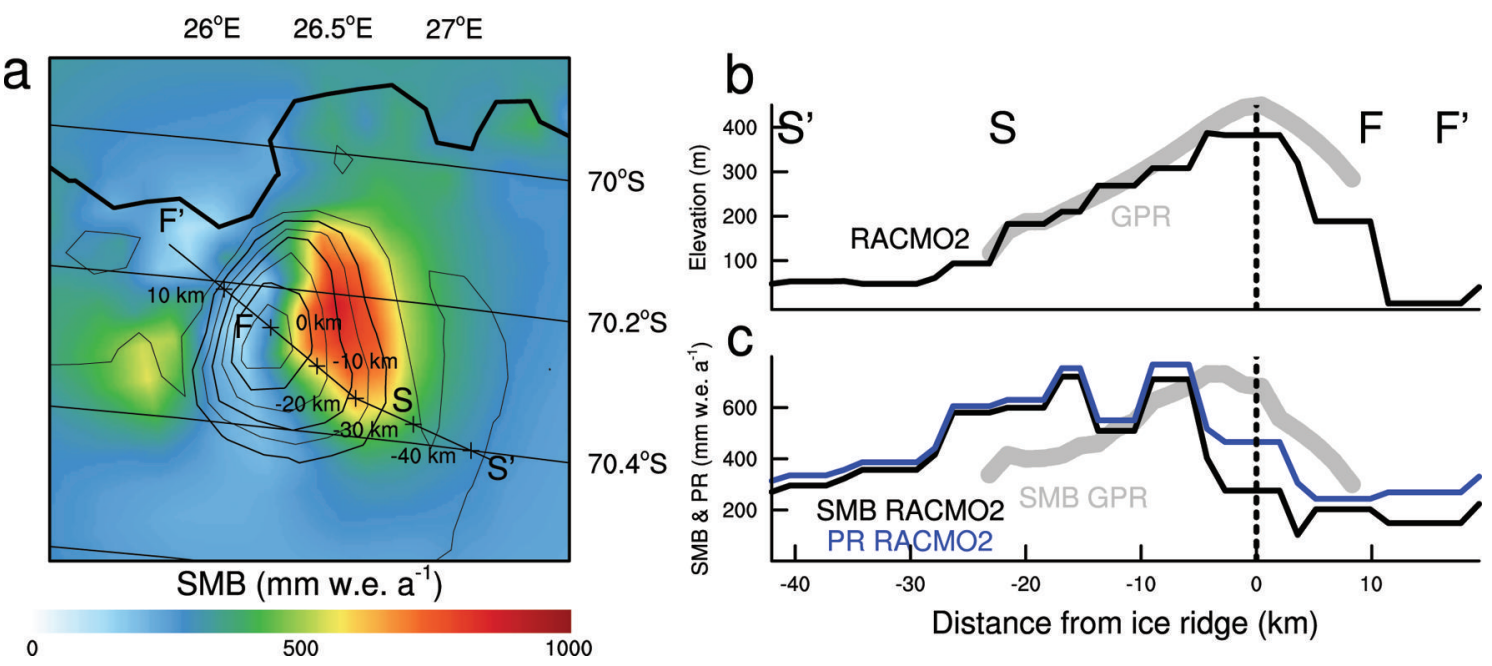

Fig. 6. (a) RACMO2 mean (2001-12) annual SMB around Derwael Ice Rise and location of transect. (b) Elevation profile and (c) mean SMB along the transect according to RACMO2 (black) and derived from the GPR observations (grey; Fig. 2). RACMO2 precipitation, PR, is shown in blue in (c). The vertical dotted line in (b, c) shows the location of the divide. The crosses and numbers in (a) correspond to the distance from the ice ridge, equivalent to the $x$-axis in $(b, c)$.

$\left(<100 \mathrm{~mm}\right.$ w.e. $\left.\mathrm{a}^{-1}\right)$. Although we have no evidence of this large SMB span from our observations, we find that the RACMO2 SMB compares relatively well with the in situ SMB observations, especially for Kupol Ciolkovskogo; in the case of Kupol Moskovskij, the location of the SMB maximum in RACMO2 is somewhat displaced to the west, which is probably influenced by a poor representation of the ice rise in the DEM. The DEM shows a small ice dome east of Kupol Moskovskij, which does not correspond to our observations.

To understand this simulated SMB variability and compare it with observations in more detail, we zoom in further on the region around Derwael Ice Rise. Figure 6a shows the simulated $\mathrm{SMB}$ and the location of the GPR transect across the ice rise, which is parallel to the prevailing near-surface wind direction. The elevation of this transect, measured by kinematic GPS, is shown in Figure 6b. The elevation in RACMO2 (derived from Bamber and others, 2009) compares well with the observed elevation, despite an underestimation $(\sim 50 \mathrm{~m})$ of the elevation of the divide. This allows for comparison between the observed and simulated $\mathrm{SMB}$ along the same transect in Figure 6c. The GPRestimated SMB shows a gradual increase from $350 \pm 40$ to $750 \pm 40 \mathrm{~mm}$ w.e. $\mathrm{a}^{-1}$ east of the divide; the maximum SMB is located $\sim 15 \mathrm{~km}$ east of the divide. From there, SMB sharply decreases in a northwesterly direction. RACMO2 captures the SMB variability reasonably well, although the $\mathrm{SMB}$ maximum is displaced to the west by $\sim 5 \mathrm{~km}$. Possible reasons for the discrepancies between model and observations, apart from the inherent model uncertainty and erroneous topography of Derwael Ice Rise in RACMO2 (Fig. 6b), can be ascribed to (1) the assumption of a constant surface snow density in the conversion process from measured two-way travel time of the GPR reflection horizons to SMB and (2) false tracking of reflection horizons in the GPR.

Next, we analyse which processes determine this significant spatial variability in SMB. Figure 7 shows the individual simulated SMB components. Precipitation clearly dominates the SMB variability, with large values on the northeastern flanks of the topographic features. This signal is primarily driven by orographic lifting of the relatively humid air that originates from the Southern Ocean. These synoptic precipitation events typically occur only a few (0-5) times per year at irregular intervals, and are related to an atmospheric net southward transport of (sub)tropical moisture (Noone and others, 1999; Reijmer and Van den Broeke, 2001; Schlosser and others, 2010; Lenaerts and others, 2013), sometimes organized in plumes or 'atmospheric rivers' (Gorodetskaya and others, 2014b). This moist air is transported in a southwesterly direction over the flat sea ice and ice shelf, until the flow encounters an ice rise or promontory, leading to locally enhanced precipitation. Note that the direction of moisture flux, driven by synoptic forcing, is northeasterly, and therefore diverges from the mean wind direction (Fig. 3), the latter typically directed from the east to southeast. On the southwestern side of the ice rise, the atmospheric air column has lost part of its moisture, resulting in a precipitation shadow, where precipitation is an estimated factor of 3-10 lower than on the northeastern sides (Fig. 7a).

Such a strong but short-lived character of DML precipitation events is evident from the SMB and snowfall record at PE base from 2009 to 2012 (Fig. 8). The years 2009 and 2011 were characterized by several large accumulation events (Lenaerts and others, 2013; Gorodetskaya and others, 2014b), whereas 2010 and 2012 had no such events. The timing of the two large accumulation events for which snowfall radar data are available (events 1 and 2 in Fig. 8) is very well captured by RACMO2. The model appears to simulate the amount of snowfall well during such events, with RACMO2 indicating $43 \mathrm{~mm}$ w.e. of snowfall during event 1 (36 $\pm 8 \mathrm{~mm}$ w.e. according to the radar, depending on the choice of the $\mathrm{Ze} / \mathrm{S}$ relationship) and $91 \mathrm{~mm}$ w.e. during event 2 ( $69 \pm 16 \mathrm{~mm}$ w.e. for the snowfall radar).

RACMO2 suggests higher SMB at PE than the observations, because the model underestimates surface lowering directly following strong snowfall events (Fig. 8); this is probably related to snow compaction (which cannot be corrected for in the observed accumulation record in the absence of continuous surface snow measurements) and/or to the model underestimating local snow erosion after accumulation events. The observed SMB was largest in 2009 (230 mm w.e.), followed by 2011 (227 mm w.e.). In 

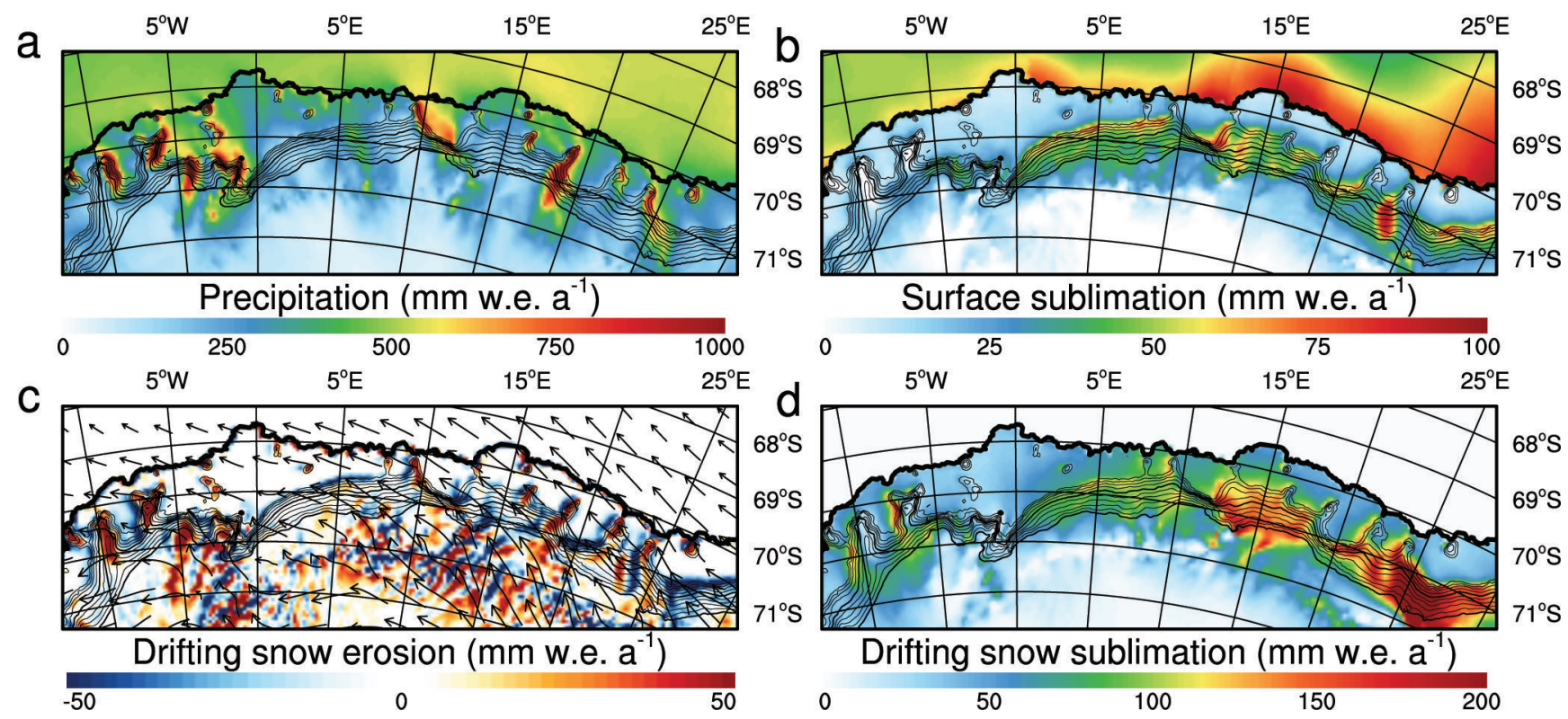

Fig. 7. RACMO2 mean (2001-12) annual SMB components: (a) precipitation; (b) surface sublimation; (c) drifting snow erosion; (d) drifting snow sublimation. Topography is shown in black contours with a resolution of $100 \mathrm{~m}$.

contrast, 2010 (23 mm w.e.) and 2012 (52 mmw.e.) were much drier years. This is also simulated in RACMO2, with high SMB in 2011 (297 mm w.e.) and 2009 (225 mm w.e.), and much lower SMB in 2010 (69 mmw.e.) and 2012 (106 mm w.e.). The model output underscores the significant interannual variability of SMB in DML.

Apart from precipitation, RACMO2 suggests that drifting snow processes are also important for the ice-rise SMB (Figs $7 \mathrm{c}$ and d). Snow erosion (20-100 mm w.e. $\mathrm{a}^{-1}$ ) occurs just alee of ice-rise ridges, where near-surface winds pick up; the eroded snow is deposited (i.e. negative $E_{\mathrm{ds}}$ ) further down the ice rise, where winds slow down again (Fig. 7c). Drifting snow sublimation is largest $\left(50-200 \mathrm{~mm}\right.$ w.e. $\mathrm{a}^{-1}$ ) in the windy and dry ice-shelf areas leeward of the ice rises. Unlike drifting snow processes, surface sublimation is small around ice rises $\left(<20 \mathrm{~mm}\right.$ w.e. $\mathrm{a}^{-1}$; Fig. $\left.7 \mathrm{~b}\right)$. Although the individual SMB components cannot be quantified, higher observed surface snow densities, the visual evidence of the presence of many more sastrugi, and larger surface snow grains in satellite products (Scambos and others, 2007) confirm that snow erosion is significant on downwind slopes of Antarctic ice rises. Drifting snow sublimation, and drifting snow erosion even more so, show strong spatial variability, not only on the regional scale, which is resolved by RACMO2 (Fig. 7b and c), but also on much finer, subkilometre scales, related to small undulations in surface topography and wind field. This is especially true in lowprecipitation regions, such as on the lee side of ice rises (Fig. 5). In light of the realistic simulation of snowfall by RACMO2 (Fig. 8), it is likely that small-scale drifting snow phenomena, which are not resolved by RACMO2, may explain, at least partly, the discrepancy between model and observations.

\section{CONCLUSIONS}

This paper presents the imprint of ice rises on the regional climate and $\mathrm{SMB}$, with a focus on coastal DML. We use a combination of high-resolution regional climate model data
(2001-12) and observational data from weather stations, snow stakes, firn cores, GPR and a snowfall radar. We demonstrate that, although ice-shelf climate and SMB are generally homogeneous, ice rises strongly enhance spatial climate and SMB variability. Despite their higher elevations, ice rises are not colder than ice shelves, as they protrude from the surface-based temperature inversion in winter. Although the near-surface winds are predominantly between east and southeast, induced by katabatic forcing, the mean moisture flux is directed from the northeast. Therefore we find highest orographic precipitation on the northeastern slopes, with a precipitation shadow on the other side. Drifting snow processes occur predominantly on the downwind (western) sides of ice rises. The resulting SMB is significantly (2-6 times) higher on northeastern ice-rise slopes than on the ice shelf.

This study has three main implications for glaciological studies. Firstly, the SMB gradient across ice rises (which is

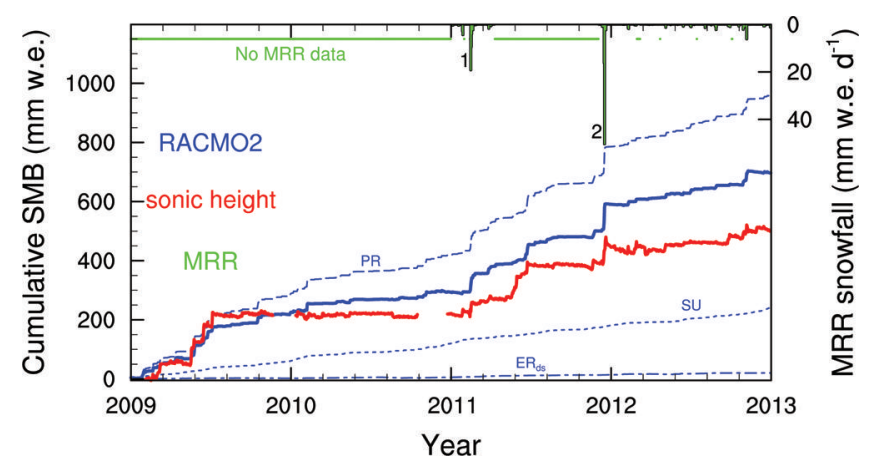

Fig. 8. Cumulative SMB for 2009-12 at PE base according to RACMO2 (blue) and the observations (red). RACMO2 SMB components are depicted with the dashed line (PR), dotted line (total sublimation) and dash-dotted line (snow erosion). The green lines show the MRR-derived daily snowfall (right axis). Note that the MRR was offline for prolonged periods before and during 2011, shown by the horizontal green dots. ' 1 ' and ' 2 ' denote snowfall events 1 (14-18 February) and 2 (13-20 December 2011). 
shown here to be a generic feature) directly translates into variable annual layer thicknesses on both sides of the divide; older ice can be found in the low-SMB regime, a higher temporal resolution in the high-SMB regime. This is of interest for ice cores drilled, for example,. within the International Partnerships in Ice Core Sciences (IPICS) $2 \mathrm{k} /$ 40k arrays (Brook and others, 2006).

Secondly, the basal mass balance of ice shelves has recently been determined in a mass-budget approach (Depoorter and others, 2013; Rignot and others, 2013), using measured ice thickness and surface velocities combined with SMB from RACMO2. However, ice rises cause a precipitation shadow on ice shelves, a feature that is not resolved in RACMO2 with such a horizontal resolution ( $27 \mathrm{~km}$; Lenaerts and others, 2012a). This results in an underestimation of the basal melt rates near the downwind side of ice rises using the mass-budget method.

Finally, the internal stratigraphy tends to arch upwards beneath the divide of some ice rises ('Raymond bumps'). This feature can be used as a proxy for the regional palaeoice-flow dynamics (e.g. Conway and others, 1999; Martín and others, 2006), by matching the arch amplitudes with various modelling scenarios. This study shows that the SMB gradient across ice rises is a topography-driven effect that persists over time, and which should be considered when interpreting the englacial stratigraphy of ice rises.

\section{AUTHOR CONTRIBUTION STATEMENT}

J.T.M.L. developed and led the study, performed the climate simulations with E.M. and analysed them with M.R.v.d.B., and wrote most of the paper. J.B., K.M., D.C., R.D., M.P. and F.P. assembled and analysed the firn-core and GPR data and contributed to the analysis of the combined results. C.H.R., I.V.G. and N.P.M.v.L. provided and analysed the weather station and radar data at PE base. All authors contributed to the writing of the manuscript.

\section{ACKNOWLEDGEMENTS}

The graphics in this paper are constructed using the NCAR Command Language (UCAR/NCAR/CISL/NETS, 2013). The idea for this study originated during the International Workshop on Antarctic Ice Rises, organized by K.M. with R. Hindmarsh in August 2013, with kind financial support of the Scientific Committee on Antarctic Research (SCAR), the Center for Ice, Climate and Ecosystems of the Norwegian Polar Institute (CICE), the Association of Polar Early Career Scientists (APECS), the Research Council of Norway, the British Antarctic Survey and the Climate and Cryosphere Project $(\mathrm{CliC})$. This research is partly funded by the Netherlands Polar Program of the Netherlands Organization of Scientific Research (NWO). D.C. is funded through a FNRS-FRIA fellowship (Fonds National de la Recherche Scientifique, Belgium). Field data on Kupol Ciolkovskogo and Kupol Moskovskij were collected by the project IceRises, funded by the Norwegian Antarctic Research Expedition and CICE.

\section{REFERENCES}

Alley RB, Blankenship DD, Rooney ST and Bentley CR (1989) Sedimentation beneath ice shelves - the view from Ice Stream B.
Mar. Geol., 85(2-4), 101-120 (doi: 10.1016/0025-3227(89) 90150-3)

Arthern RJ, Winebrenner DP and Vaughan DG (2006) Antarctic snow accumulation mapped using polarization of $4.3 \mathrm{~cm}$ wavelength microwave emission. J. Geophys. Res., 111(D6), D06107 (doi: 10.1029/2004JD005667)

Arthern RJ, Vaughan DG, Rankin AM, Mulvaney R and Thomas ER (2010) In situ measurements of Antarctic snow compaction compared with predictions of models. J. Geophys. Res., 115(F3), F03011 (doi: 10.1029/2009JF001306)

Bamber JL, Gomez-Dans JL and Griggs JA (2009) A new $1 \mathrm{~km}$ digital elevation model of the Antarctic derived from combined satellite radar and laser data - Part 1: data and methods. Cryosphere, 3(1), 101-111 (doi: 10.5194/tc-3-101-2009)

Bindschadler RA, Roberts EP and Iken A (1990) Age of Crary Ice Rise, Antarctica, determined from temperature-depth profiles. Ann. Glaciol., 14, 13-16

Bindschadler R and 17 others (2011) Getting around Antarctica: new high-resolution mappings of the grounded and freely floating boundaries of the Antarctic ice sheet created for the International Polar Year. Cryosphere, 5(3), 569-588 (doi: 10.5194/tc-5-569-2011)

Brook EJ, Wolff E, Dahl-Jensen D, Fischer H and Steig EJ (2006) The future of ice coring: International Partnerships in Ice Core Sciences (IPICS). PAGES News, 14(1), 6-10

Connolley WM (1996) The Antarctic temperature inversion. Int. J. Climatol., 16(12), 1333-1342 (doi: 10.1002/(SICl)1097-0088 (199612)16:12<1333::AID-JOC96>3.0.CO;2-6)

Conway H, Hall BL, Denton GH, Gades AM and Waddington ED (1999) Past and future grounding-line retreat of the West Antarctic ice sheet. Science, 286(5438), 280-283 (doi: 10.1126/science.286.5438.280)

Cuffey KM and Paterson WSB (2010) The physics of glaciers, 4th edn. Butterworth-Heinemann, Oxford

Dee DP and Uppala S (2009) Variational bias correction of satellite radiance data in the ERA-Interim reanalysis. Q. J. R. Meteorol. Soc., 135(644), 1830-1841 (doi: 10.1002/qj.493)

Depoorter MA and 6 others (2013) Calving fluxes and basal melt rates of Antarctic ice shelves. Nature, 502(7469), 89-92 (doi: 10.1038/nature12567)

Drews R, Rack W, Wesche C and Helm V (2009) A spatially adjusted elevation model in Dronning Maud Land, Antarctica, based on differential SAR interferometry. IEEE Trans. Geosci. Remote Sens., 47(8), 2501-2509 (doi: 10.1109/TGRS.2009.2016081)

Drews R, Martín C, Steinhage D and Eisen O (2013) Characterizing the glaciological conditions at Halvfarryggen ice dome, Dronning Maud Land, Antarctica. J. Glaciol., 59(213), 9-20 (doi: 10.3189/2013JoG12J134)

Eisen $\mathrm{O}$ and 15 others (2008) Ground-based measurements of spatial and temporal variability of snow accumulation in East Antarctica. Rev. Geophys., 46(RG2), RG2001 (doi: 10.1029/ 2006RG000218)

Ettema J, Van den Broeke MR, Van Meijgaard E, Van de Berg WJ, Box JE and Steffen K (2010) Climate of the Greenland ice sheet using a high-resolution climate model: Part 1: evaluation. Cryosphere, 4(4), 511-527 (doi: 10.5194/tc-4-511-2010)

Fernandoy F, Meyer H, Oerter H, Wilhelms F, Graf $W$ and Schwander J (2010) Temporal and spatial variation of stableisotope ratios and accumulation rates in the hinterland of Neumayer station, East Antarctica. J. Glaciol., 56(198), 673-687 (doi: 10.3189/002214310793146296)

Fricker HA, Coleman R, Padman L, Scambos TA, Bohlander J and Brunt KM (2009) Mapping the grounding zone of the Amery Ice Shelf, East Antarctica using InSAR, MODIS and ICESat. Antarct. Sci., 21(5), 515-532 (doi: 10.1017/S095410200999023X)

Gorodetskaya IV, Van Lipzig NPM, Van den Broeke MR, Mangold A, Boot W and Reijmer CH (2013) Meteorological regimes and accumulation patterns at Utsteinen, Dronning Maud Land, East Antarctica: analysis of two contrasting years. J. Geophys. Res., 118(D4), 1700-1715 (doi: 10.1002/jgrd.50177) 
Gorodetskaya IV and 6 others (2014a) Cloud and precipitation properties from ground-based remote sensing instruments in East Antarctica. Cryos. Discuss., 8, 4195-4241 (doi: 10.5194/tcd-84195-2014)

Gorodetskaya IV, Tsukernik M, Claes K, Ralph MF, Neff WD and Van Lipzig NPM (2014b) The role of atmospheric rivers in anomalous snow accumulation in East Antarctica. Geophys. Res. Lett., 41(17), 6199-6206 (doi: 10.1002/2014GL060881)

Helm V, Humbert A and Miller H (2014) Elevation and elevation change of Greenland and Antarctica derived from CryoSat-2. Cryosphere, 8(4), 1539-1559 (doi: 10.5194/tc-81539-2014)

Horgan HJ and Anandakrishnan S (2006) Static grounding lines and dynamic ice streams: evidence from the Siple Coast, West Antarctica. Geophys. Res. Lett., 33(18), L18502 (doi: 10.1029/ 2006GL027091)

Hubbard B and 6 others (2013) Ice shelf density reconstructed from optical televiewer borehole logging. Geophys. Res. Lett., 40(22), 5882-5887 (doi: 10.1002/2013GL058023)

Hughes T (1977) West Antarctic ice streams. Rev. Geophys. Space Phys., 15(1), 1-46 (doi: 10.1029/RG015i001p00001)

Jenkins A and 6 others (2010) Observations beneath Pine Island Glacier in West Antarctica and implications for its retreat. Nature Geosci., 3(7), 468-472 (doi: 10.1038/ngeo890)

Jezek KC and Bentley CR (1983) Field studies of bottom crevasses in the Ross Ice Shelf, Antarctica. J. Glaciol., 29(101), 118-126

King JC, Anderson PS, Vaughan DG, Mann GW, Mobbs SD and Vosper SB (2004) Wind-borne redistribution of snow across an Antarctic ice rise. J. Geophys. Res., 109(D11), D11104 (doi: 10.1029/2003JD004361)

Kleiner T and Humbert A (2014) Numerical simulations of major ice streams in western Dronning Maud Land, Antarctica, under wet and dry basal conditions. J. Glaciol., 60(220), 215-232 (doi: 10.3189/2014JoG13J006)

König-Langlo GC (2011) Meteorological synoptical observations from Neumayer Station. (Tech. Rep. 2011-01) Helmholtz Center for Polar and Marine Research, Alfred Wegener Institute, Bremerhaven

Kuipers Munneke P, Van den Broeke MR, Lenaerts JTM, Flanner MG, Gardner AS and Van de Berg WJ (2011) A new albedo parameterization for use in climate models over the Antarctic ice sheet. J. Geophys. Res., 116(D5), D05114 (doi: 10.1029/ 2010JD015113)

Lenaerts JTM, Van den Broeke MR, Van de Berg WJ, Van Meijgaard E and Kuipers Munneke P (2012a) A new, high-resolution surface mass balance map of Antarctica (1979-2010) based on regional atmospheric climate modeling. Geophys. Res. Lett., 39(4), L04501 (doi: 10.1029/2011GL050713)

Lenaerts JTM and 6 others (2012b) Modeling drifting snow in Antarctica with a regional climate model: 1. Methods and model evaluation. J. Geophys. Res., 117(D5), D05108 (doi: 10.1029/2011JD016145)

Lenaerts JTM, Van Meijgaard E, Van den Broeke MR, Ligtenberg SRM, Horwath M and Isaksson E (2013) Recent snowfall anomalies in Dronning Maud Land, East Antarctica, in a historical and future climate perspective. Geophys. Res. Lett., 40(11), 2684-2688 (doi: 10.1002/grl.50559)

Lenaerts JTM and 6 others (2014) Extreme precipitation and climate gradients in Patagonia revealed by high-resolution regional atmospheric climate modeling. J. Climate, 27(12), 4607-4621 (doi: 10.1175/JCLI-D-13-00579.1)

Looyenga H (1965) Dielectric constant of heterogeneous mixtures. Physica, 31(3), 401-406 (doi: 10.1016/0031-8914(65)90045-5)

Martín C, Hindmarsh RCA and Navarro FJ (2006) Dating ice flow change near the flow divide at Roosevelt Island, Antarctica, by using a thermomechanical model to predict radar stratigraphy. J. Geophys. Res., 111(F1), F01011 (doi: 10.1029/2005JF000326)

Martín C, Gudmundsson GH and King EC (2014) Modelling of Kealey Ice Rise, Antarctica, reveals stable ice-flow conditions in
East Ellsworth Land over millennia. J. Glaciol., 60(219), 139-146 (doi: 10.3189/2014JoG13J089)

Matrosov SY (2007) Modeling backscatter properties of snow fall at millimeter wavelengths. J. Atmos. Sci., 64(5), 1727-1736 (doi: 10.1175/JAS3904.1)

Matsuoka K, Pattyn F, Callens D and Conway H (2012) Radar characterization of the basal interface across the grounding zone of an ice-rise promontory in East Antarctica. Ann. Glaciol., 53(60 Pt 1), 29-44 (doi: 10.3189/2012AoG60A106)

Miège $C$ and 6 others (2013) Southeast Greenland high accumulation rates derived from firn cores and ground-penetrating radar. Ann. Glaciol., 54(63 Pt 2), 322-332 (doi: 10.3189/2013AoG63A358)

Nereson NA and Waddington ED (2002) Isochrones and isotherms beneath migrating ice divides. J. Glaciol., 48(160), 95-108 (doi: 10.3189/172756502781831647)

Nicolas JP and Bromwich DH (2011) Climate of West Antarctica and influence of marine air intrusions. J. Climate, 2(1), 49-67 (doi: 10.1175/2010JCLI3522.1)

Noone D, Turner J and Mulvaney R (1999) Atmospheric signals and characteristics of accumulation in Dronning Maud Land, Antarctica. J. Geophys. Res., 104(D16), 19191-19211 (doi: 10.1029/1999JD900376)

Pattyn F and 8 others (2012) Melting and refreezing beneath Roi Baudouin Ice Shelf (East Antarctica) inferred from radar, GPS, and ice core data. J. Geophys. Res., 117(F4), F04008 (doi: 10.1029/2011JF002154)

Reijmer CH and Van den Broeke MR (2001) Moisture sources of precipitation in western Dronning Maud Land, Antarctica. Antarct. Sci., 13(2), 210-220 (doi: 10.1017/ S0954102001000293)

Rignot E, Jacobs S, Mouginot J and Scheuchl B (2013) Ice shelf melting around Antarctica. Science, 341(6143), 266-270 (doi: 10.1126/science.1235798)

Scambos TA, Haran TM, Fahnestock MA, Painter TH and Bohlander J (2007) MODIS-based Mosaic of Antarctica (MOA) data sets: continent-wide surface morphology and snow grain size. Remote Sens. Environ., 111(2-3), 242-257 (doi: 10.1016/j. rse.2006.12.020)

Schlosser E, Manning KW, Powers JG, Duda MG, Birnbaum G and Fujita K (2010) Characteristics of high-precipitation events in Dronning Maud Land, Antarctica. J. Geophys. Res., 115(D14), D14107 (doi: 10.1029/2009JD013410)

Spikes VB, Hamilton GS, Arcone SA, Kaspari S and Mayewski P (2004) Variability in accumulation rates from GPR profiling on the West Antarctic plateau. Ann. Glaciol., 39, 238-244 (doi: 10.3189/172756404781814393)

UCAR/NCAR/CISL/VETS (2013) NCAR Command Language (NCL), Version 6.1.2. Computational Information Systems Laboratory http://www.ncl.ucar.edu/citation/shtml

Van de Berg WJ, Van den Broeke MR, Reijmer $\mathrm{CH}$ and Van Meijgaard E (2006) Reassessment of the Antarctic surface mass balance using calibrated output of a regional atmospheric climate model. J. Geophys. Res., 111(D11), D11104 (doi: 10.1029/ 2005JD006495)

Van den Broeke MR, Van As D, Reijmer CH and Van de Wal RSW (2004) The surface radiation balance in Antarctica as measured with automatic weather stations. J. Geophys. Res., 109(D9), D09103 (doi: 10.1029/2003JD004394)

Van den Broeke M, Van de Berg WJ and van Meijgaard E (2006) Snowfall in coastal West Antarctica much greater than previously assumed. Geophys. Res. Lett., 33(2), L02505 (doi: 10.1029/2005GL025239)

Van Lipzig NPM, King JC, Lachlan-Cope T and Van den Broeke MR (2004) Precipitation, sublimation, and snow drift in the Antarctic Peninsula region from a regional atmospheric model. J. Geophys. Res., 109(D24), D24106 (doi: 10.1029/ 2004JD004701)

Van Wessem JM, Reijmer CH, Lenaerts JTM, Van de Berg WJ, Van den Broeke MR and Van Meijgaard E (2014) Updated cloud physics in a regional atmospheric climate model improves the 
modelled surface energy balance of Antarctica. Cryosphere, 8(1), 125-135 (doi: 10.5194/tc-8-125-2014)

Waddington ED, Neumann TA, Koutnik MR, Marshall H-P and Morse DL (2007) Inference of accumulation-rate patterns from deep layers in glaciers and ice sheets. J. Glaciol., 53(183), 694-712 (doi: 10.3189/002214307784409351)

Wesche C, Riedel S and Steinhage D (2009) Precise surface topography of the grounded ice ridges at the Ekströmisen, Antarctica, based on several geophysical data sets. ISPRS $\%$.
Photogramm. Remote Sens., 64(4), 381-386 (doi: 10.1016/j. isprsjprs.2009.01.005)

Winkelmann R, Levermann A, Martin MA and Frieler K (2012) Increased future ice discharge from Antarctica owing to higher snowfall. Nature, 492(7428), 239-242 (doi: 10.1038/ nature11616)

Wright AP and 9 others (2013) Sensitivity of the Weddell Sea sector ice streams to sub-shelf melting and surface accumulation. Cryos. Discuss., 7(6), 5475-5508 (doi: 10.5194/tcd-7-5475-2013)

MS received 10 April 2014 and accepted in revised form 12 August 2014 